\title{
Latent class instrumental variables and the monotonicity assumption
}

Stuart G. Baker*

\begin{abstract}
A key aspect of the article by Lousdal on instrumental variables was a discussion of the monotonicity assumption. However, there was no mention of the history of the development of this assumption. The purpose of this letter is to note that Baker and Lindeman and Imbens and Angrist independently introduced the monotonicity assumption into the analysis of instrumental variables. The letter also places the monotonicity assumption in the context of the method of latent class instrumental variables.
\end{abstract}

Keywords: Instrumental variables, Complier average causal effect, CACE, Local average treatment effect (LATE)

Lousdal [1] reviewed four basic assumptions of instrumental variable methodology and noted that the fourth basic assumption of monotonicity has received little attention in the literature. I would like to call attention to an omission in the Lousdal review, namely that the original work on the monotonicity assumption was not cited. Baker and Lindeman [2] and Imbens and Angrist [3] independently formulated an instrumental variables approach with the monotonicity assumption, which Imbens and Angrist called "monotonicity". Baker et al. [4] provided historical background to the development of this methodology. They also coined the term latent class instrumental variables for an instrumental variable methodology involving randomization group or time period (treated like a randomization group) as the instrumental variable and having the following three characteristics. First, there are four latent classes (often called alwaystaker, never-takers compliers, and defiers [5]) based on treatment received if assigned to each group or time period. Second, the exclusion restriction assumption says that randomization group or time period does not affect

This comment refers to the article available online at https://doi.org/10.1186/ s12982-018-0069-7.

*Correspondence: sb16i@nih.gov

Biometry Research Group, National Cancer Institute, Bethesda, MD 20892. USA the probability of outcome among always-takers and never-takers. Third, the monotonicity assumption specifies no defiers. As noted by Lousdal [1], with an instrumental variable of randomization group, the assumptions of relevance and exchangeability hold. Under these assumptions, the method of latent class instrumental variables estimates the effect of treatment among the latent class of compliers, which has various names including the effect of treatment received, [2] the local average treatment effect (LATE), [3] and the complier average causal effect (CACE) [6]. The terms LATE and CACE generally refer to differences in outcome among compliers. The method of latent class instrumental variables also estimates the relative risk for outcomes among compliers [7].

\section{Acknowledgements \\ Not applicable.}

\section{Authors' contributions}

SGB is the sole author. The author read and approved the final manuscript

\section{Funding}

Dr. Baker is employed by the National Cancer Institute, National Institutes of Health. The content is solely the responsibility of the author and does not necessarily represent the official views of the National Institutes of Health.

\section{Availability of data and materials}

Not applicable.

Ethics approval and consent to participate Not applicable.

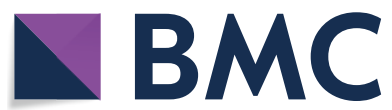
License, which permits use, sharing, adaptation, distribution and reproduction in any medium or format, as long as you give appropriate credit to the original author(s) and the source, provide a link to the Creative Commons licence, and indicate if changes were made. The images or other third party material in this article are included in the article's Creative Commons licence, unless indicated otherwise in a credit line to the material. If material is not included in the article's Creative Commons licence and your intended use is not permitted by statutory regulation or exceeds the permitted use, you will need to obtain permission directly from the copyright holder. To view a copy of this licence, visit http://creativecommons.org/licenses/by/4.0/. The Creative Commons Public Domain Dedication waiver (http://creat ivecommons.org/publicdomain/zero/1.0/) applies to the data made available in this article, unless otherwise stated in a credit line to the data. 


\section{Consent for publication}

Not applicable.

\section{Competing interests}

The author declares that he has no competing interests.

Received: 7 December 2019 Accepted: 28 February 2020

Published online: 19 March 2020

\section{References}

1. Lousdal ML. An introduction to instrumental variable assumptions, validation and estimation. Emerg Themes Epidemiol. 2018;15:1.

2. Baker SG, Lindeman KS. The paired availability design: a proposal for evaluating epidural analgesia during labor. Stat Med. 1994;13:2269-78.
3. Imbens GW, Angrist JD. Identification and estimation of local average treatment effects. Econometrica. 1994;62:467-75.

4. Baker SG, Kramer BS, Lindeman KL. Latent class instrumental variables. A clinical and biostatistical perspective. Stat Med. 2016; 35:147-160.

5. Angrist JD, Imbens GW, Rubin DB. Identification of causal effects using instrumental variables. J Am Stat Assoc. 1996;92:444-55.

6. Imbens GW, Rubin DB. Bayesian inference for causal effects in randomized experiments. Ann Stat. 1997;25:305-27.

7. Baker SG, Kramer BS. Simple maximum likelihood estimates of efficacy in randomized trials and before-and-after studies, with implications for meta-analysis. Stat Meth Med Res. 2005; 14; 349-67.

\section{Publisher's Note}

Springer Nature remains neutral with regard to jurisdictional claims in published maps and institutional affiliations.
Ready to submit your research? Choose BMC and benefit from:

- fast, convenient online submission

- thorough peer review by experienced researchers in your field

- rapid publication on acceptance

- support for research data, including large and complex data types

- gold Open Access which fosters wider collaboration and increased citations

- maximum visibility for your research: over $100 \mathrm{M}$ website views per year

At BMC, research is always in progress.

Learn more biomedcentral.com/submissions 